\title{
344. 高感度片面システムの肋骨接線撮影への適応
}

Application of High Sensitive Single Screen System

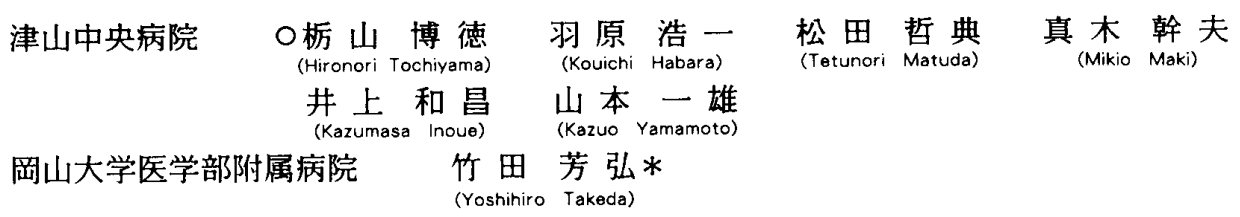

〈目的〉

肋骨撮影は縌隔、肺野上に写しだされ、 技術的に難しいうえ高画質の得にくい 部位である。

そこで、患者の被曝、画質の向上、術者 の負担を考虑し当院における撮影システ ムを検討した。

\section{〈方法〉}

1 物理特性

各システムの物理特性を検討した。

2 視覚評価

2 点啫好法、点数評価法により比較

検討した。

〈結果〉

1 物理特性（図 1、2、3）

2 視覚評価

2-1２点㖺好法による評価（図 4）

片面システムは、画質の向上をみとめ、ラチチュ

一ドも考え合わせて中高齢者への適用を考えた。

2-2 点数法による評価 [若年齢層対応システム]

2-2-1 各システムの点数評価（図5)

$70 \%$ 以の評価を得たのは、60〜80 $\mathrm{mR}$ の時で、

この時の第 6 肋骨外側部の浱度は、0.65 0.95で熊

谷らの腰椎最適濃度よりも若干低い濃度域を示

した。

2-2-2 両システムの点数評価（図6、7）

チェストタイプ・フイルムの再撮影率は、現行

システムに比べ約 $10 \%$ の低下を認めた。

〈結語〉

1 中高齢者に対しては、やや感度が低いが、粒状性に

優れ高画質が得られる片面システムを適用することに した。

2 若年秢層に対しては、画質を下げることなく再撮影 率を抑えるためにチェストタイプ・フイルムを適用す ることにした。
図1特性曲線

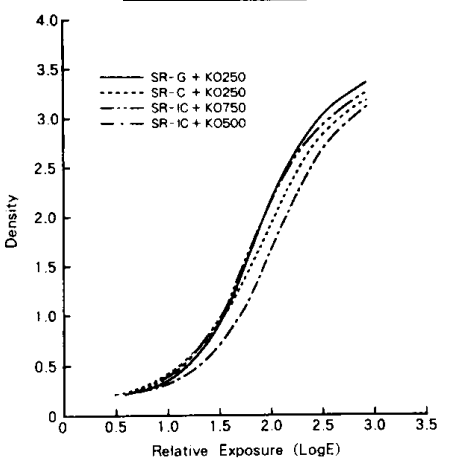

图 3 拉状性 (R.M.S.)

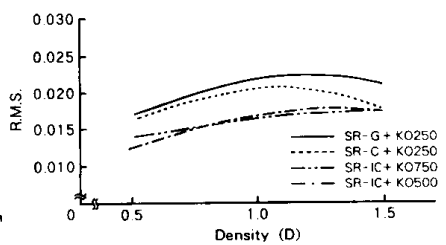

图4 2 点些好法による判定

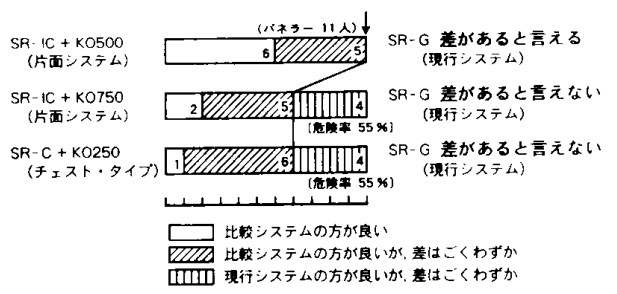

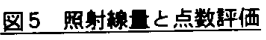
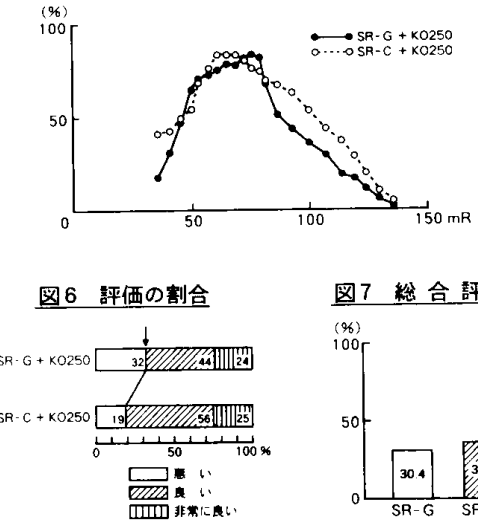

図7絰合呯価

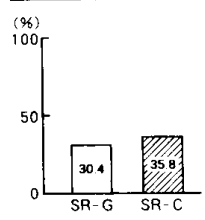

